\title{
STUDENT PROJECT: DATA CAPTURE AND TAXONOMIC DETERMINATION OF CYCADALES AT THE ROYAL BOTANIC GARDEN EDINBURGH
}

\author{
James Clugston ${ }^{1}$
}

\begin{abstract}
This paper discusses a curatorial review of the Cycadales in the Living Collection at the Royal Botanic Garden Edinburgh (RBGE) following the methodology described by Frachon et al. (2009). It provides an understanding of the cycads in the Living Collection and the diversity of the group represented at RBGE. The paper also describes the determination process and any changes in identification during the course of the project. This project was carried out as part of the secondyear project of the HND in Horticulture with Plantsmanship at RBGE.
\end{abstract}

\section{INTRODUCTION}

The Cycads (order Cycadales) are the oldest extant seed plants. Although they are grouped with other gymnosperms they are only distantly related. The order dates back over 200 million years to the Mesozoic era, and the plants are often considered to be 'living fossils'. This makes them extremely appealing to a public obsessed with all things dinosaur, and cycads offer great potential as a major driver of public interest in botanic garden collections.

The trunk, referred to as the caudex, of many cycad species is often used as a food source, and other parts are used for traditional medicines. Exploitation for the horticulture trade as ornamental plants is a further major threat to these plants, and all species are now protected. Many cycads are highly endangered, and some species have become extinct in the wild and survive only in cultivation. This is the case with Encephalartos woodii Sander where only one male plant is known from the wild.

There are currently two families and ten genera represented within the Cycadales. Cycadaceae, a monotypic family containing Cycas L., and Zamiaceae, containing Stangeria T. Moore, Bowenia Hook. Ex Hook, Dioon Lindl., Encephalartos Lehm., Macrozamia Miq., Lepidozamia Regel, Ceratozamia Brongn., Microcycas (Miq.) A. DC. and Zamia L. (Zgurski et al., 2008). See Appendix 2 for a summary of genus-level diversity.

Botanic gardens are critical safe havens for cycads - these plants are important for their educational and research value and must be preserved. Any botanic garden collection of cycads must be properly curated in order for maximum conservation and educational value to be gained from the collection. Understanding the species, sex, origin and condition of living stock is imperative for our global inventory of the group

1. James Clugston is a student on the BSc Hons in Horticulture with Plantsmanship at Royal Botanic Garden Edinburgh. Address: 20A Inverleith Row, Edinburgh, EH3 5LR

Email: j.clugston@rbge.org.uk 
and for our understanding of its genetic diversity. A well-curated collection provides essential information for optimal growing conditions, can inform collection and acquisition policies, and ensures that public displays highlight the plants with the most interesting stories (Rae, 2006).

\section{CYCADS AT THE ROYAL BOTANIC GARDEN EDINBURGH}

The Indoor Living Collection at the Royal Botanic Garden Edinburgh (RBGE) contains over 6,000 species of wild-collected and cultivated-origin plants (Rae et al., 2006). Cycads are present in the display and in 'back-up' collections - mainly as part of geographical or general-interest collections rather than as active research collections. It is one of the largest cycad collections in the UK. Southern African species are best represented, reflecting the legacy of B.L. Burtt and Olive Hilliard, two of the most active researchers in the region. Nevertheless, the group was recently identified as being in need of curation, because the specimens were:

- poorly documented - some specimens believed to be from the wild have little or no collection information, while others are known to have come from other botanic gardens, so their wild origin status is unknown

- misidentified - many specimens in the collection needed to be redetermined because they have been misidentified and there have been changes in classification

- poorly labelled - labels were often missing, inaccurate, incomplete or poorly positioned

- inappropriately sited - many of the plants in the collection were not planted in optimum conditions, mainly as a legacy of the way the collection was assembled and displayed since the late 1960s. Plants were housed in conditions that were too humid and poorly drained, resulting in significant problems with growth and pathogens.

The collection was thus identified as an ideal subject for inclusion in RBGE's Data Capture Project (DCP). This project aims to curate and collect as much useful information as possible on the Living Collection at RBGE. The DCP includes a set of protocols designed to maximise the value and usefulness of plant collections at RBGE and elsewhere. The purpose and protocols of the DCP are detailed by Frachon et al. (2009). This paper discusses the practical application of the DCP using the Cycadales collection as a case study. This was carried out as a student undergraduate project by the author and is hereafter referred to as the Cycad DCP.

\section{PROJECT AIMS}

The Cycad DCP aimed to curate the Cycadales in the Living Collection following the protocols set by RBGE and the publication Data Management for Plant Collections: Handbook of Best Practice (Watson and Thomas, 2002). 


\section{Objectives}

In order to curate the Living Collection effectively and maximise the value of the Cycad DCP the following objectives were identified:

1. To completely stock-check all plants in the Living Collection, assessing their health and recording their condition and life-cycle stage as well as making measurements and observations of key morphological characteristics used in cycad identification.

2. To ensure RBGE's database was up to date with complete information on both the Living Collection and accepted cycad taxonomy.

3. To determine identifications across the entire Living Collection to species level.

4. To collect voucher specimens, including carpological material where relevant, and leaf material for DNA studies.

5. To create a photographic record of all specimens.

The final output of the project was a horticultural report which includes a list of recommendations and suggestions for the long-term improvement of the collection, and this is included in this paper. This paper also provides a genus-level identification guide for those managing other cycad collections (Appendix 1) as well as a complete list of Cycadales in the Living Collection at RBGE (Appendix 2).

\section{DATA CAPTURE PROTOCOL}

The data capture protocol is a two-part process involving a preliminary survey and more in-depth data capture. In order to improve the information retained about the collection within the database the current condition of each plant is required to be assessed. The database used at RBGE is BG-BASE ${ }^{\mathrm{TM}}$ (Walter \& O'Neal, 1985-2010). RBGE has set up protocols for the data capture process (Frachon et al., 2009) which are currently the most important steps in directly improving the Living Collection and the information held within the database. Following these protocols, which include stock-check, identification, verification and recommendation for improvement of the collection, will have a positive impact on the collection and will make it a valuable asset for botanical and scientific research. Information will be catalogued, voucher specimens prepared and all taxa identified and verified. The process and key findings are outlined below.

\section{Preliminary survey}

The first part of the Cycad DCP, a preliminary survey of the stock, involved taking a list of all plantings where cycads are planted (also known as a 'bed list') from the database and locating each of the individual plants, including all accessions and qualified propagules of these. Plants without labels could be confidently identified to individual qualified accessions in all cases, or were identified as plants needing new qualifiers. 'Qualifiers' are given to individual plants in cases where there are a number 
of plants with one accession number placed in more than one location; they are added as capital letters at the end of the accession number (12349876 A, $12349876 \mathrm{~B}$ and so on). For all plants without labels, or with inaccurate information such as misrecorded accession numbers, temporary labels were printed and replacement labels ordered. The preliminary survey took around eight hours to complete.

It is essential that each living plant is assigned an individual qualified accession number (Watson \& Thomas, 2002). Where multiple plants existed under a single genotype qualifier a new qualifier was generated. The preliminary survey revealed 67 specimens of Cycadales across the entire Living Collection under 55 accession numbers. The following accessions each had two or more individuals growing in the collection. These 13 duplicates therefore represented 19 per cent of the collection.

Encephalartos caffer (Thunb.) Lehm. 19922130 A \& B

Encephalartos hildebrandtii A. Braun \& C.D. Bouché 19764004 A \& B

Encephalartos transvenosus Stapf \& Burtt Davy 19620600 A \& B

Cycas rumphii Miq. 19696594 A \& B

Ceratozamia hildae G.P. Landry \& M.C. Wilson 19696386 A \& B

Encephalartos natalensis R.A. Dyer \& I. Verd. 19696766 A \& B

Lepidozamia hopei Regel 19330467

The following were accessions for which new qualifiers had to be generated:

Bowenia serrulata (W. Bull) Chamb. 19900106 A, B \& C

Ceratozamia hildae G.P. Landry \& M.C. Wilson 20042006 A \& C

Zamia integrifolia L. f. 19950695 A \& B

Cycas seemannii A. Braun 19881361 A, B \& C

In one case, two distinct species of Lepidozamia Regel were determined under the same accession (19330467 A \& B). The policy regarding how to deal with this situation is laid out in Watson and Thomas (2002) and it will only support splitting an existing multi-taxon accession to create a new one if one or both of the taxa are wild-collected or otherwise important heritage collections. The larger of the two specimens, determined as $L$. hopei, was the only plant of this species represented in the Living Collection. The other specimen was already accessed in the collection. Both plants of L. peroffskyana were of garden origin and therefore less desirable than wild specimens, so only the already-accessed specimen was retained, and the second individual (19330467 B) was de-accessed and donated to Dundee Botanic Garden.

One specimen of Macrozamia communis L.A.S. Johnson (19697151A) had not been found during the previous stock-check in 1999 but was refound during the current stockcheck. A number of specimens of Encephalartos and Ceratozamia were missing their labels, and so temporary labels needed to be generated and the status of the plants (stated as 'not found') changed on the database. The sheer size of the Indoor Living Collection 
at RBGE and the limited staff time available for stock-checking these rediscoveries highlight the value of focused, specialised data capture projects in large botanic garden collections.

\section{Detailed Cycad Data Capture Project}

Following the preliminary survey, a more involved data capture protocol was followed to bring together as much useful information as possible on the collection and on individual accessions and plants. This involved collecting a complete suite of data including measurements of individual specimens, records of key identifying characters, photographs and voucher specimens, including carpological and DNA material where possible. All specimens were identified and a comprehensive database update undertaken. The findings were summarised in a horticultural report and recommendations for the collection were produced.

\section{Individual measurements}

Individual whole-plant measurements including height and spread were made. Caudex diameter and length were also recorded because these can be good indicators, especially in smaller species, of sexual maturity. For example, in Encephalartos caffer (Thunb.) Lehm, once the caudex diameter is more than $70 \mathrm{~mm}$ the plant is usually able to produce strobili (cones). Mature leaf-size measurements were estimated and the presence of suckers recorded. Suckering is a natural growth stage of many cycads. It is most prominent in South African Encephalartos Lehm species, and suckering is generally considered to be healthy unless it is in response to major crown damage. As well as a general health indicator, suckers can also be useful for species identification as plants revert to juvenile growth on suckers. Juvenile foliage is often an important morphological character in separating species in Encephalartos.

\section{Voucher specimens}

Prior to this project the herbarium at RBGE had only a small number of cultivated taxa represented in the preserved collection. In the course of the Cycad DCP, voucher specimens from each individual cycad in the Living Collection were collected and dried. These specimens were linked to the verification field on BG-BASE ${ }^{\mathrm{TM}}$ and will help in future with identification and determination to species level of living and herbarium collections. Specimens were dried in the drying room at RBGE, in approximately $29^{\circ} \mathrm{C}$ and 38 per cent relative humidity. The process took between three and five days in a fast-drying system (called a Leiden Frame). Complete drying times depended on the specimen, those with bulkier leaves and thicker cuticles taking longer to dry than others. 


\section{Carpological specimens}

Strobili provide some of the key characters for identification at all levels in Cycadales; their importance meant that the collection of carpological specimens was an essential part of the Cycad DCP. When available the megasporangiate strobilus (female) or microsporangiate strobilus (male) were collected and dried to be stored as carpological specimens in the preserved collection. These were then linked to the determination and voucher specimen on BG-BASE ${ }^{\mathrm{TM}}$. Ideally the specimen should be complete, but in some cases only old and partially complete material was available. For example, with Ceratozamia kuesteriana Regel. only the megasporophylls were present. These were still collected, however, in order to help confirm the identity of the plant.

The most challenging specimen was a female strobilus of Dioon spinulosum R.A. Dyer \& Eichler that weighed $8 \mathrm{~kg}$. This took three months to dry fully in the drying room at RBGE. In spite of the long drying time, the tissues preserved very well, with no apparent rotting or fungal damage.

\section{DNA samples}

A DNA sample was taken from each individual accession. This is important because it can be used for genetic sequencing and other analyses in order to improve our understanding of the genetics of specimens in the Living Collection.

Mature and immature leaflets (if available) were collected from all accessions unless the specimen was in a condition where it was not possible to collect material. A sealable collection bag was filled with silica gel and a humidity indicator that changes colour if it becomes saturated. On each bag was added the accession number and qualifier, the date of collection and the DCP collection number. A jeweller's tag was added to each bag, with the accession number and verification number written on each side in pencil.

Leaf material was cut into small pieces and placed into the sealed bags. Silica gel is used because it quickly draws all the moisture from the cells, greatly reducing the ability of nucleases and other enzymes to degrade the DNA. If DNA were to be dried in a humid environment, the genetic material could be fragmented and lost.

\section{Photographic record}

Photographs were taken of all plants in the Living Collection, using a Canon EOS 450D, and saved as jpeg files (typically 4,272 $\times 2,848$ pixels). Images included one of the plant where it was growing along with key identifying characters including suckers, attachment of leaflets, shape of terminal and maiden leaflets, presence of lower and reduced leaflets (including pinnacanths and spines), presence or absence of cataphylls and presence or absence of trichomes. Where present, reproductive structures including whole strobili and the architecture of the sporophylls were photographed as well. Other elements of the overall condition of the plant were photographed as appropriate, including any damage or the presence of pests and diseases. The photographs were stored on BG-BASE ${ }^{\mathrm{TM}}$ and linked through the accession number of the plant in the photograph. 


\section{Characters recorded during determination}

At this point it is important to provide a definition of the term 'determination': 'Name determined - the identification of a plant that has previously been unknown at the family, genus, species or infraspecific level' (Frachon et al., 2009).

Important characters for identification were noted depending on the genus or species observed. These characters were then used for the determinations (also sometimes referred to as 'identifications' or 'verifications'). For example, in determining the specimen of Encephalartos natalensis R.A. Dyer \& I. Verd., plants were identified using a range of vegetative and sexual characteristics as follows:

Leaves: dark green, pinnate, petiolate.

Leaflets: connected sub-oppositely to rachis, long ovate-broadly lanceolate, pungent, oblique tip, lower leaflets reduced to spines or pinnacanths more prominent on juvenile growth (suckers). E. natalensis juvenile growth can be highly dentate with pungent tips which usually reduce with age.

Strobili: both mature specimens with the collection were identified as male. Microstrobilus had a prominent peduncle, $400 \mathrm{~mm}$ total length, and microsporophylls were rigid and warty.

This set of characteristics allowed separation from the otherwise very similar E. altensteinii Lehm. (Table 1).

These characteristics were entered directly into the database as they describe all the key features for identifying a species and contain both sexual and vegetative features.

\begin{tabular}{|c|c|c|}
\hline Plant parts & Encephalartos altensteinii Lehm. & $\begin{array}{l}\text { Encephalartos natalensis } \\
\text { R.A. Dyer \& I. Verd. }\end{array}$ \\
\hline Petiole & $\begin{array}{l}\text { Petiolate, unarmed, with no } \\
\text { distinct lower or reduced spines or } \\
\text { pinnacanths }\end{array}$ & $\begin{array}{l}\text { Petiolate or sessile (only usually on juvenile } \\
\text { growth), armed with prominent spines, formed } \\
\text { by reduced leaflets or pinnacanths }\end{array}$ \\
\hline Leaflets & Lanceolate-long ovate & Lanceolate-oblanceolate \\
\hline Margins & $\begin{array}{l}\text { Entire (rarely dentate, mainly juvenile } \\
\text { leaves) }\end{array}$ & $\begin{array}{l}\text { Highly dentate on juvenile to immature } \\
\text { growth; margins become entire as the plant } \\
\text { matures }\end{array}$ \\
\hline Rachis & $\begin{array}{l}\text { Leaflets connected sub-oppositely; } \\
\text { terminal leaflets form a distinct V } \\
\text { shape }\end{array}$ & $\begin{array}{l}\text { Leaflets connected sub-oppositely; leaflets } \\
\text { often overlap incubously }\end{array}$ \\
\hline $\begin{array}{l}\text { Central axis } \\
\text { of caudex }\end{array}$ & $\begin{array}{l}\text { Cataphylls present, with no distinct } \\
\text { hair }\end{array}$ & Cataphylls present, with dense tomentose hair \\
\hline
\end{tabular}

Table 1 Comparative characteristics for Encephalartos altensteinii and E. natalensis. 


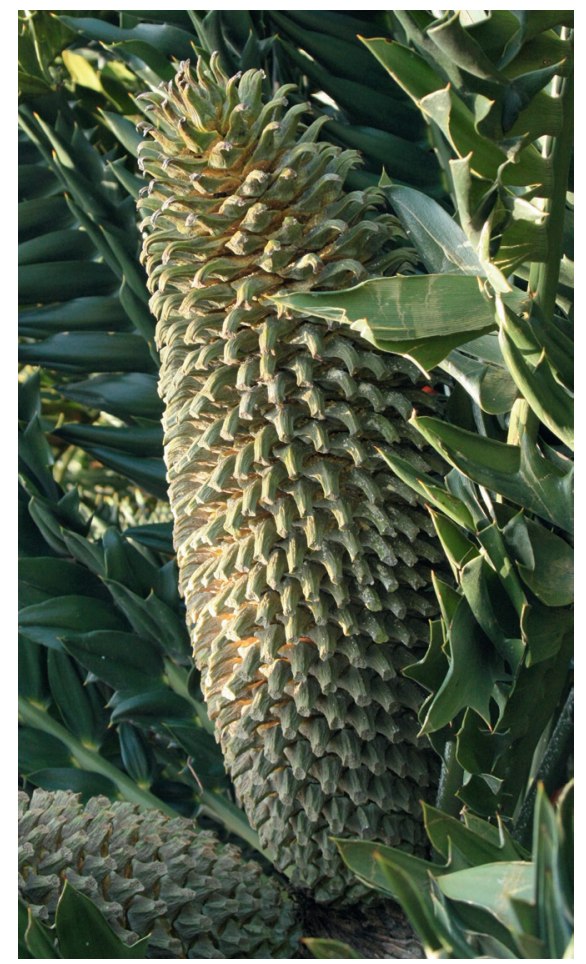

Fig. 1 Microsporangiate strobilus of Encephalartos latifrons growing in Kirstenbosch Botanic Garden, Cape Town, August 2009. Photo: James Clugston.

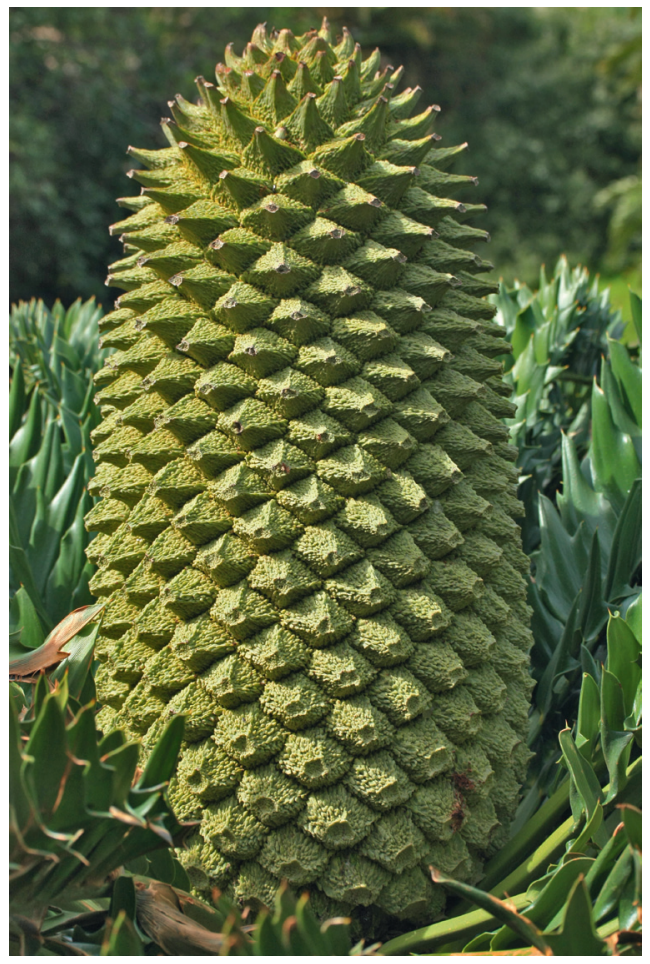

Fig. 2 Megasporangiate strobilus of Encephalartos latifrons growing in Kirstenbosch Botanic Garden, Cape Town, August 2009. Photo: James Clugston.

\section{Species level identifications and determinations across the entire Living Collection}

Each specimen in the Living Collection was identified from the morphological characters observed. The status of the name it was given was also checked. This identification process was carried out independently of the name on the label or records on the database. In 47 cases these determinations effectively verified existing identifications. Eight accessions (15 per cent) of the Living Collection were newly determined or had their names updated (Table 2). As taxonomic names can become out of date over time through synonymy or names being otherwise invalid, for example because of prior usage, it was essential to check currently accepted names.

The steps involved in determination were as follows:

- The latest formal classification of Cycadales, A Formal Classification of the Extant Cycads (Stevenson, 1992) was used to check the status of each family.

- The status of each name, using the latest edition of The World List of Cycads (Hill et al., 2007) was checked and changed where appropriate. 
- The key to separate genera was used from Cycads of the World (Jones, 2002) and The Cycad Pages (Hill, 2004).

Available diagnostic characteristics were checked against the protocol whenever possible; in some cases, however, the protologue (the collection of literature describing the species) was not in English and was difficult to read. Each species was cross-checked against a minimum of three valid references, such as papers, books and websites.

Specimens in preserved collections were compared with living collections for diagnostic characteristics that may be lost in the drying process; for example a crosssection of the petiole of Stangeria eriopus shows distinct vascular bundles that are often lost when the specimen is dried.

\begin{tabular}{|c|c|c|}
\hline Acc_num & Old name & New name \\
\hline $19331056 * A$ & Ceratozamia sp. & Ceratozamia kuesteriana Regel. \\
\hline $\begin{array}{l}19764003 * \mathrm{~A} \\
19696386 * \mathrm{~A} \\
19900644 * \mathrm{~A} \\
19754186 * \mathrm{~A}\end{array}$ & Ceratozamia mexicana Brongn. & Ceratozamia robusta Miq. \\
\hline $19680553 * A$ & $\begin{array}{l}\text { Encephalartos hildebrandtii A. Braun } \\
\text { \& C.D. Bouche }\end{array}$ & Encephalartos altensteinii Lehm. \\
\hline $\begin{array}{l}19696594 * \mathrm{~A} \\
19680547 * \mathrm{~A} \\
19680547 * \mathrm{C}\end{array}$ & Cycas circinalis $\mathrm{L}$. & Cycas rumphii Miq. \\
\hline
\end{tabular}

Table 2 New determinations and name changes in the Living Collection of Cycadales at RBGE.

\section{Problematic species during the determination process}

During the determination process there were a number of taxa that proved challenging in various ways. Many of the plants in the Living Collection have insufficient collection information and in some cases have been deemed to be of non-wild origin by default. With many species of Cycas L. identification to species level can be difficult or almost impossible without known locality, country of origin or sexual characteristics. With some species of Cycas the megasporophylls are the main separating characteristics.

Factors that can make determination of Cycadales difficult are as follows:

Lack of collection information or insufficient data: in some taxa of Cycadales the morphological characters can be very similar between species. The difference between two separate taxa can sometimes be simply geographic separation. This might have been the case with the determination of Cycas thouarsii R. Br. ex Gaudich. and $C$. rumphii Miq. However, there were fortunately enough female strobili on the specimens at RBGE. Thus Norstog and Nicholls (1997) was consulted and it was found that "Cycas 
thouarsii resembles C.rumphii in most respects, but the blade of the megasporophyll is narrower and longer $(2-3 \mathrm{~cm}$ wide vs. about $4 \mathrm{~cm} ; 10 \mathrm{~cm}$ long vs. $6-8 \mathrm{~cm})$ and its margin is crenulate to undulate (with rounded lobes)." (Norstog and Nicholls, 1997). The collection was therefore found to contain Cycas rumphii, and a hybrid of C. rumphii and C. thouarsii, but not straight $C$. thouarsii.

The condition of the specimens: when cycads are grown in conditions that may not be ideal, for example if light levels are low or too much water is present, this can change the appearance and habit of the plant. This is the case with Encephalartos transvenosus Stapf \& Burtt Davy. The specimens of this species in the RBGE collection were atypical as they were grown in lower light levels than the plants would experience in their native habitat, but the distinctive overlapping (incubous) leaflet arrangement was retained, so the plants could still be identified.

The lack of sufficient morphological characters: when carrying out a determination of any plant species this can make identification difficult. The use of all available characteristics is vital in determining a plant to species level. With cycads some species can be identified purely on a vegetative basis, and strobili are not as important as they are with other species in ascertaining determination. This is the case with Encephalartos horridus (Jacq.) Lehm. (Fig. 3) with its glaucous and spinose-lobed leaflets.

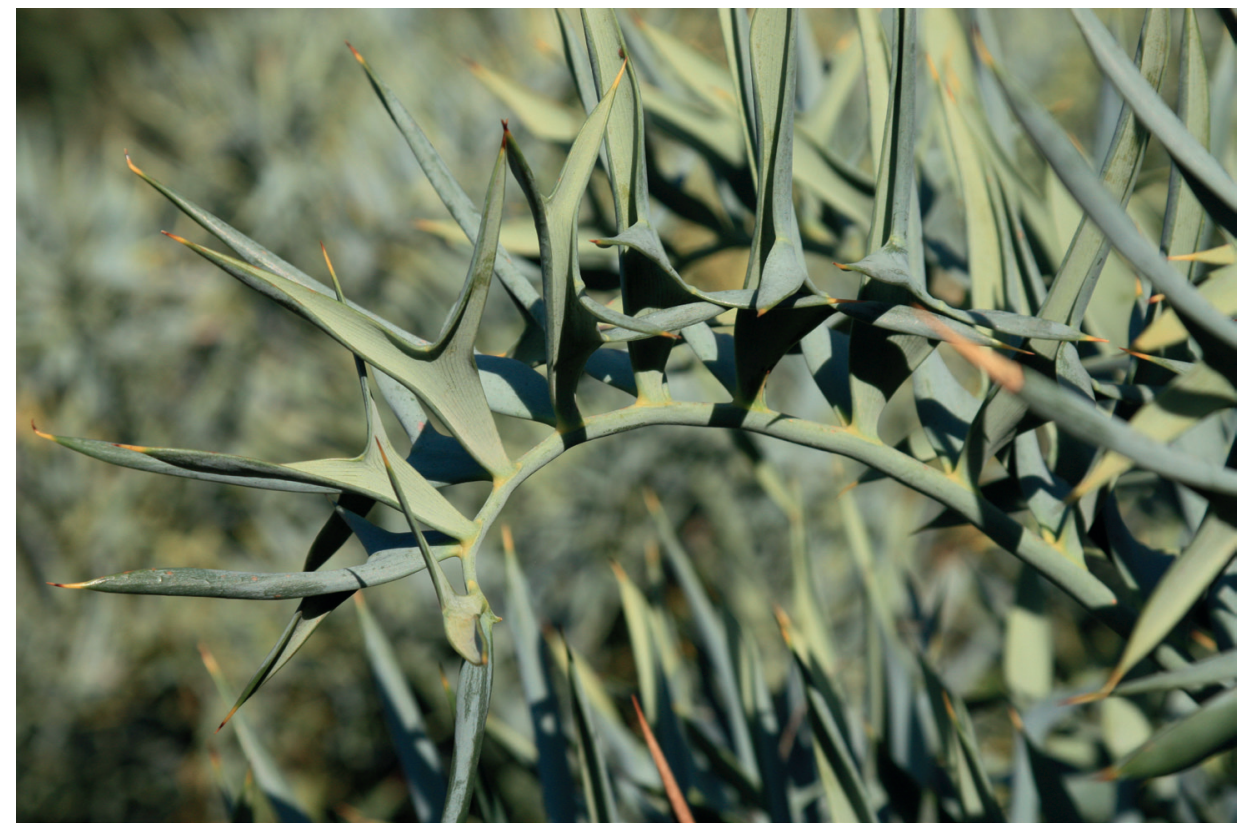

Fig. 3 Leaf detail of Encephalartos horridus growing in Kirstenbosch Botanic Garden, Cape Town, August 2009. Photo: James Clugston. 


\section{Database update}

To ensure that the database was up to date with complete information on both the living specimens and accepted cycad taxonomy, the following tables in the database were updated:

- data source: the verifications on the database have references added and each reference has its own data source number. All papers, journals and books not currently listed on the database were added for information.

- names: each cycad name represented within the collection was updated using The World List of Cycads (Hill et al., 2007). This meant that any possible name changes and new names were entered in the database, for example 170750 Ceratozamia robusta Miq. The names table also includes distribution information which will be printed on the label.

- distributions: the update in this table included information on the latest IUCN status of each plant name, which was obtained using The World List of Cycads (Hill et al., 2007).

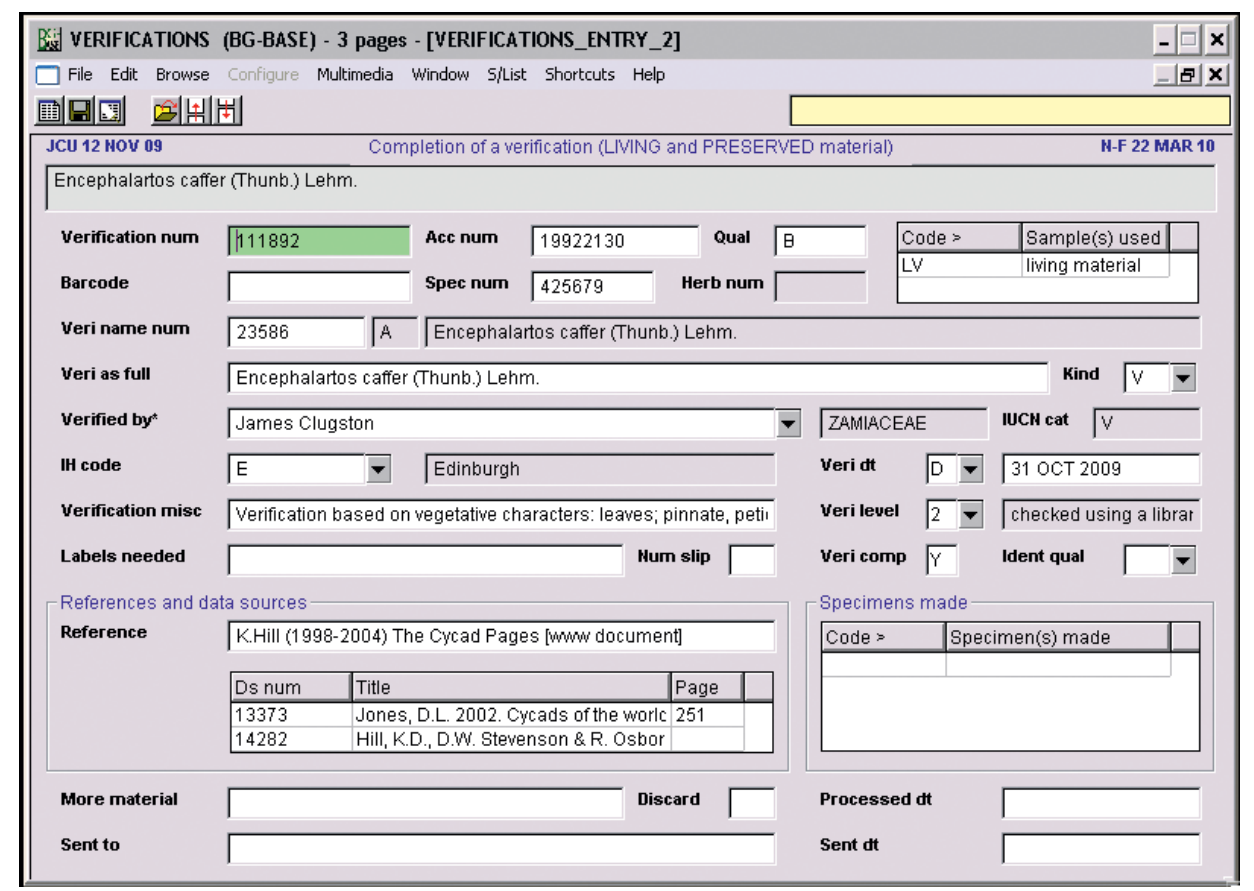

Fig. 4 Verification table on BG-BASE ${ }^{\mathrm{TM}}$ that is used to enter information and references about 


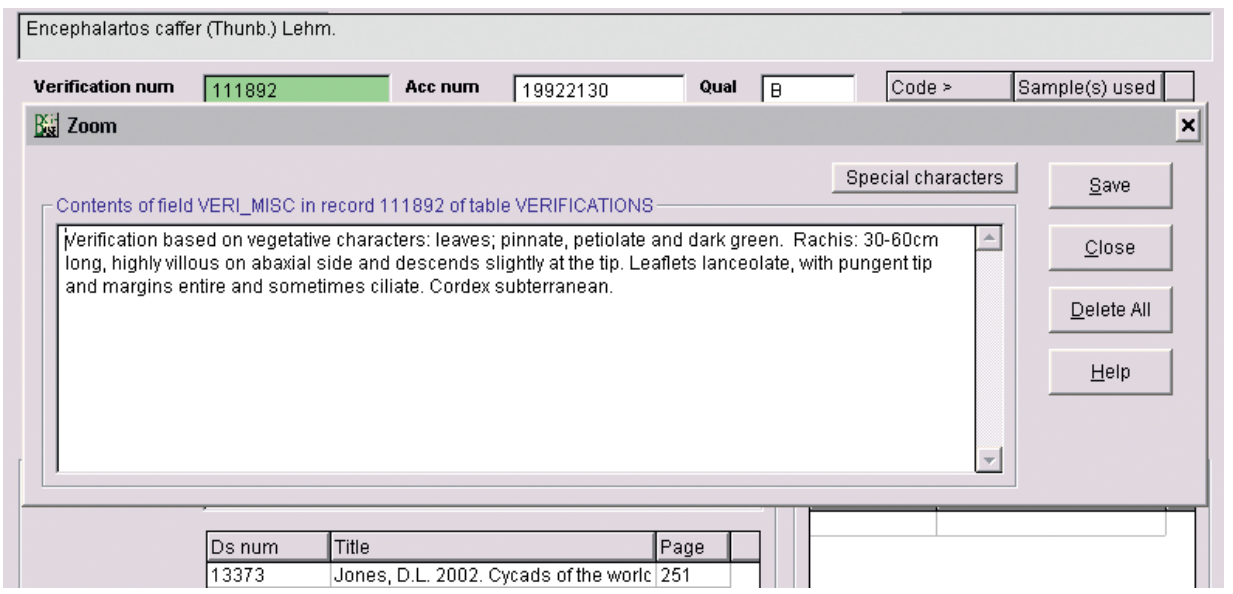

Fig. 5 Miscellaneous file on $B G-B A S E^{\mathrm{TM}}$ showing the main identifiable characters of a species and any other important information that may be required.

\section{COLLECTION SUMMARY}

The final survey of the collection showed that nine out of ten genera (90 per cent) were represented across the two currently accepted families in Cycadales:

- Cycadaceae - monotypic (Cycas)

- Zamiaceae - eight representatives from nine genera (Bowenia, Ceratozamia, Dioon, Encephalartos, Lepidozamia, Macrozamia, Stangeria, Zamia).

The monotypic genus Microcycas (Zamiaceae) is the only one not currently represented in the collection.

There are now 35 species (11.5 per cent of total cycad diversity) represented in the Living Collection at RBGE. This compares very favourably with the wider collection of plants at RBGE (c. 16 per cent of generic diversity and 5 per cent of species diversity across terrestrial plants).

Twelve accessions ( 21 per cent) were wild-collected and forty-three (78 per cent) were of garden or unknown origin. This collection therefore provides an excellent representation of Cycadales - even in view of the relatively low proportion of wildcollected specimens ( 21 per cent as opposed to the target 60 per cent for RBGE's Living Collections).

\section{CONCLUSIONS AND RECOMMENDATIONS}

The Cycad DCP resulted in the name changes of four taxa, due to both vegetative and sexual characteristics that were available. There were four specimens of Cycas 
within the Living Collection, and these were labelled as Cycas circinalis L., which is in fact very rare within cultivation and is quite a distinctive species. $C$. circinalis has a distinctive wide undulating lamina on the blade of the megasporophyll, which is less pronounced in $C$. rumphii and $C$. thouarsii. There is only one specimen of $C$. circinalis represented in the Living Collection. The other specimens have undergone a name change to $C$. rumphii.

The Cycad DCP has outlined problematic taxa which are difficult to identify to species level because of the poor condition of some of these specimens. These plants need to be removed and replaced with material of known wild origin. This would contribute towards the RBGE Collection Policy, which aims to raise the wild origin content of the collection to 60 per cent over ten years (Rae, 2006).

One very important finding, shown in the results in Table 2, was a specimen of Ceratozamia kuesteriana. This species is very rarely seen in cultivation or in many botanic gardens. The plant came into the collection as Microcycas calocoma (Miq.) A.DC. and was then renamed to Encephalartos sp. The two distinct horns on the bulla of the sporophylls clearly show that it is Ceratozamia.

A number of specimens were evidently very old, and therefore of great value. Based on their caudex size, two specimens of Encephalartos (19380474 A \& 19696766 A) were estimated at around 300 years old. These are world-class specimens and are almost certainly derived from wild-collected caudex material brought into cultivation long before the species was recognised in 1951, and probably even before the very similar E. altensteinii in 1834 (Hill et al., 2007). As there is no collection data for these accessions, the plants are treated as being of garden origin and therefore of relatively little importance. This somewhat arbitrary approach to curating such plants could endanger some superb specimens and needs to be addressed in the Collections Policy. It may be that a survey of E. natalensis in other gardens throughout the world would show these specimens to be champion plants, and this is certainly something worth investigating.

Both Encephalartos natalensis 19696766 B and E. lehmannii 19633450 A come from the drier regions of South Africa; even though many species of Encephalartos are able to adapt to wetter and more shaded conditions, E. lehmannii (Fig. 6) prefers full sun and has adapted by developing a glaucous coating on the surface of its leaflets. This aids survival in the arid lands of the Karoo Desert. Both these plants are now located in bed G07 in the Arid Lands display glasshouse, which should be the ideal place for their healthy growth.

As they were badly overgrown and outcompeted by surrounding plants, the three plants of Bowenia serrulata (W. Bull) Chamb 19900106* A, B \& C need to be moved into a better position but remain in the same bed.

Encephalartos caffer (Thunb.) Lehm 19922130 B was growing in the glasshouses containing the back-up collection. It has now been moved to the Arid Lands display glasshouse where it should thrive because it is better adapted to the drier conditions found in that glasshouse. 


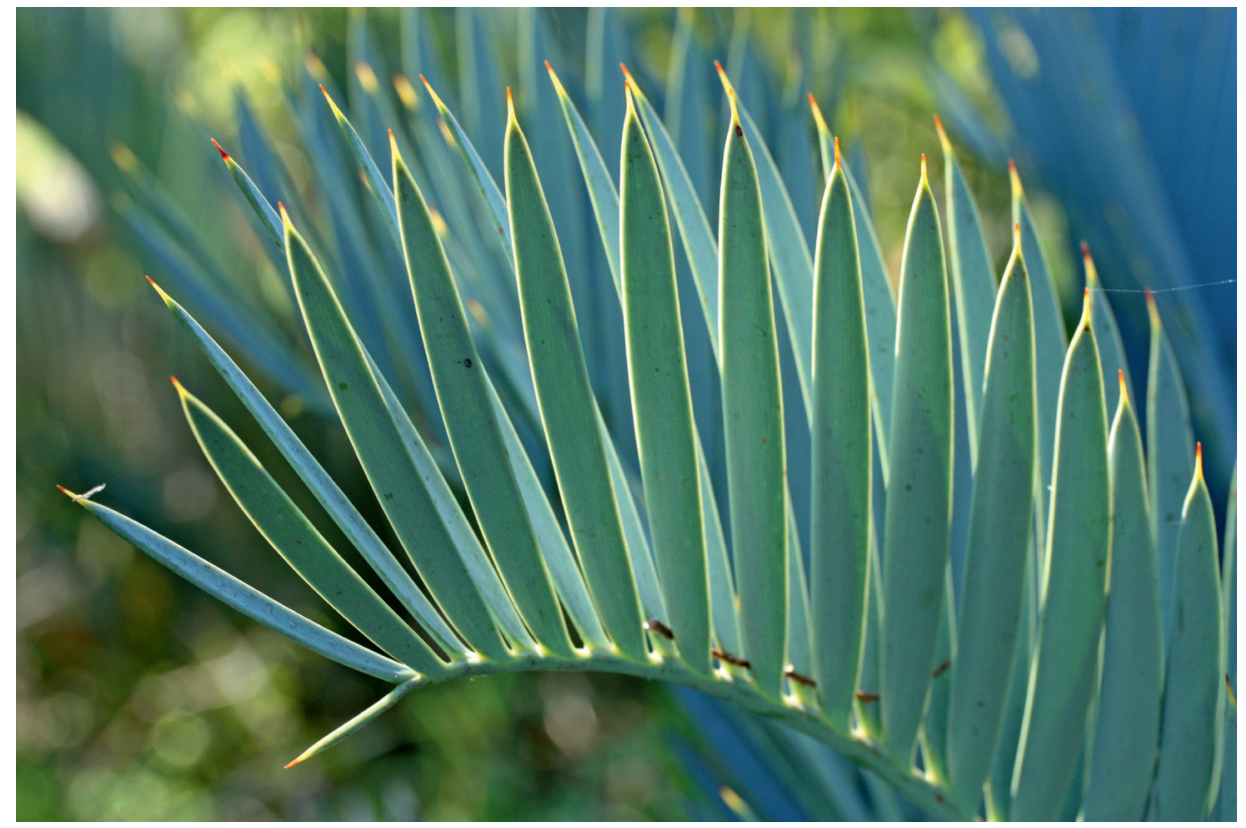

Fig. 6 Leaf detail of Encephalartos lehmannii growing in Kirstenbosch Botanic Garden, Cape Town, August 2009. Photo: James Clugston.

\section{CHALLENGES INVOLVED IN THE DCP}

\section{Herbarium specimens}

Physical size of leaves: Many species of cycads have very large leaves; for example, the leaves of Lepidozamia hopei are often over $2 \mathrm{~m}$ long. When the leaves are collected for voucher specimens, they must be cut into the terminal, maiden and lower or reduced section, which usually contains part of the rachis.

Collection and drying for carpological specimens: The strobili from many specimens of Cycadales can be of considerable size and mass. The megasporangiate strobilus collected from Dioon spinulosum, for example, weighed $8 \mathrm{~kg}$. Cones of this size have a considerable mass in the central axis and must be dried correctly to prevent rotting.

Thickness of leaves: The physical bulk of cycad leaves means that they take longer to dry than specimens with thinner leaves. The longer the drying process takes, the less uniform the specimens.

Prior to the collection of voucher specimens it is important to understand the morphological characteristics that define a particular species. These features must be noted during data capture or when collecting a voucher specimen. If the features that are important for identification of a species are not present this must be noted. 


\section{Photography}

Creating a photographic record of the plants within the Living Collection is an important part of adding records to the database. When composing photographs of plants in the glasshouses success depends on light levels. There are other factors that can be influenced in order to help with any challenging light conditions encountered, such as the following.

The correct aperture and shutter speed must be selected to allow for speed as well as the required depth of field. Using minimum $28 \mathrm{~mm}$ F2 lens with image stabiliser (IS) will help in fluctuating light conditions. ISO settings can help improve the camera's sensitivity to light but increasing the ISO speed will make the picture grainier. There are ways to avoid this with an IS lens, and by using a camera with a better noise-reduction processor and using a lower ISO speed such as 800-1,600.

Using a flash to maximise detail on each photograph should be avoided, as this will create unneeded over-exposure.

\section{SUMMARY}

This summary provides a brief overview of the project from its initial aim through to its conclusion:

Aim: Curate the Living Collection of Cycadales at RBGE. Standardised data capture protocols will provide the complete framework for this process.

\section{Objectives:}

1. Verify the taxonomy and identification of Cycadales in the Living Collection at RBGE.

2. Create a photographic record of all specimens.

3. Collect voucher herbarium specimens, including carpological and DNA specimens.

4. Complete a horticultural report including a list of recommendations to improve the cycad collection and the data-capture process itself.

Action: A stock-check of each plant was done to include the label; the condition of the plant; its height and spread; its reproductive state; and its key characters for identification. Voucher specimens were collected, dried and mounted and, if available, a carpological specimen was also collected. The next step was to update the name status of each species following the latest classification. These updated names were then applied to the individual specimens, providing a complete, accurately identified and up-to-date collection. All information was recorded on BG-BASE ${ }^{\mathrm{TM}}$, the data collection management database used at RBGE. A horticultural report was then submitted with suggestions for improvements to the cycad Living Collection and a review of the data capture protocol. 
Findings: Sixty-four specimens were stock-checked; this included six accessions which were split into multiple qualifiers. Sixty-two voucher specimens and twenty-four carpological specimens were collected, pressed, dried and linked to verifications. Sixty-two specimens were verified and nine name changes were processed. One new species was added to the database. A number of poor specimens were recommended for removal and replacement with known wild-origin material. There are now 35 species represented in the Living Collection at RBGE.

Conclusions: Multiples of taxa will be removed if not of known wild origin and replaced with wild-origin material in order to improve the long-term botanical value of the collection. Other specimens growing in conditions that were not suited to the species were moved into better locations in the glasshouses at RBGE.

\section{CONCLUSION}

Although the cycad collection at RBGE is relatively small when compared with the rest of the collection, it nonetheless represents 11.5 per cent of the diversity in Cycadales and has nine out of ten genera represented within the Living Collection. However, because only 21 per cent of the cycad collection is of known wild origin, it falls well below the 60 per cent target set by RBGE.

The Cycad DCP has been an excellent opportunity to learn about the collection and has brought to light problems that exist in the glasshouses. There are many excellent specimens represented in the Living Collection, which shows the vast diversity of living cycads at RBGE.

\section{ACKNOWLEDGEMENTS}

I wish to express my greatest thanks to David Knott and Leigh Morris for allowing me to carry out this project and to Greg Kenicer and Phil Lusby for their support and guidance throughout. I owe my greatest gratitude to Martin Gardner and Natacha Frachon for their continued support and guidance when undertaking the data-capture protocols. Other RBGE staff whom I would like to thank are Bruce Robertson and Fiona Inches for allowing me to collect material from the public display houses, Dr Kerry Walter for help with BG-BASE ${ }^{\mathrm{TM}}$ updates, Louise Galloway for information about the history of the collection and Ian Mason for his support and help with pressing and collecting voucher specimens.

\section{GLOSSARY}

Bulla (pl. bullae) - expanded shield-like distal portion of cycad sporophylls Cataphyll - modified leaf, serving to protect the main growing point of the cycad Incubous - describes an arrangement of leaflets where each leaflet is partially shielded by the next distal leaflet when viewed from above (adaxially) 
Megasporangiate strobilus - ovule-bearing cone of the female plant, also referred to as 'seed cone' and sometimes abbreviated to 'megastrobilus'

Megaspores - spores that give rise to a female gametophyte

Microsporangiate strobilus - pollen-bearing cone of the male plant, sometimes abbreviated to 'microstrobilus'

Microspores - pollen grains

Microsporophyll - sporophyll-bearing microsporangia

Pinnacanth - photosynthetic spine formed from a greatly reduced leaflet

Platyspermic - describes seeds that are flattened so as to be not radially symmetrical

Radiospermic - describes seeds that are radially symmetric, including all cycad genera except Cycas.

Sporophyll - modified leaf that is of a reproductive structure

Strobilus (pl. strobili) - reproductive structure of cycads and conifers

Trichome - small hair or scale of epidermal origin

\section{REFERENCES}

FRACHON, N., GARDNER, M.F. \& RAE, D. (2009). The Data Capture Project at the Royal Botanic Garden Edinburgh. Sibbaldia, 7, 77-82. Royal Botanic Garden Edinburgh. Available online: http://plantnet.rbgsyd.nsw.gov.au/PlantNet/cycad (accessed 28 May 2010).

HILL, K.D., OSBORNE, R. \& STEVENSON, D.W. (2007). The World List of Cycads (La Lista Mundial De Cícadas). Proceedings of 7th International Conference on Cycad Biology. New York Botanic Gardens Press, New York, 453-483.

JONES, D.L. (2002). Cycads of the World. Smithsonian Institute Press, Washington, DC.

NORSTOG, K.J. \& NICHOLLS, T.J. (1997). The Biology of the Cycads. Cornell University Press, New York.

RAE, D. (2006). Collection Policy for the Living Collection. Royal Botanic Garden Edinburgh.

RAE, D., CUBEY, R., GARDNER, M., LATTA, J. \& WALTER, K. (2006). Royal Botanic Garden Edinburgh Catalogue of Plants. Royal Botanic Garden Edinburgh.

SPENCER, P.S., MASAYUKI, O. \& PALMER, V.S. (1987). Cycad use and motor neurone disease in KII peninsula of Japan. The Lancet, 2(8,573), 1,462-1,463.

STEVENSON, D.W. (1992). A formal classification of the extant Cycads. Brittonia, 44. New York Botanical Gardens, New York, 220-223.

WALTER, K.S. \& O'NEAL, M J. (1985-2010). BG-BASETM (Collection Management Software). BG-BASE inc. \& BG-BASE (UK) Ltd. Available online: http://www.bg-base.com

WATSON, M. \& THOMAS, P. (2002). Data Management for Plant Collections: A Handbook of Best Practice. Royal Botanic Garden Edinburgh.

ZGURSKI, J.M., HARDEEP RAI, S., FAI, Q.M., BOGLER, D.J., FRANCISCO-ORTEGA, J. \& GRAHAM, S.W. (2008). How well do we understand the overall backbone of cycad phylogeny? New insights from a large, multigene plastid data set. Molecular Phylogenetics and Evolution, 47(3), 1,232-1,237. 
APPENDIX 1: MAIN MORPHOLOGICAL CHARACTERISTICS OF CYCADALES

The order Cycadales contains around 300 extant taxa (Hill, 2004) where current classification stands (Zgurski et al., 2008), and there are two extant families in the order Cycadales: Cycadaceae and Zamiaceae.

\section{Cycadaceae}

Cycas L.

- megasporophylls leaf-like, lacking central axis with megaspores attached below sporophyll lamina

- leaves pinnate; petiole often with aculeate spines parallel down rachis

- leaflets circinate when first emerging; leaflets of all species have distinct mid-vein

- seeds platyspermic.

\section{Zamiaceae}

Bowenia Hook. Ex Hook. F.

- leaves bi-pinnate

- megaspores attached above megasporophyll

- seeds radiospermic

- young leaflets circinate.

Ceratozamia Brongn.

- spinose and often aculeate spines on petiole and rachis

- bi-apiculate, pungent non-photosynthetic spines on the terminal facet of the bullae on both megasporophylls and microsporophylls.

Dioon Lindl.

- terminal surface of megasporophylls compressed and flattened, and lacking lateral lobe

- megaspores attached on basal stalk-like pedicel.

Encephalartos Lehm.

- bullae of megasporophylls are distinctly thickened, terminal surface often faceted

- megaspores attached directly behind lateral lobe of megasporophyll

- lower leaflets often reduced to pungent pinnacanths

- peduncle of strobili often bearing decurrent cataphylls.

Lepidozamia Regel

- leaflets decurrent and attached on adaxial surface of rachis

- terminal surface of sporophylls elongated and becomes spine-like

- leaves arranged in parastichy. 
Macrozamia Miq.

- leaflets with distinct callous at the point of attachment to the rachis

- terminal surface of sporophyll forms a distinct and often pungent spine.

Microcycas (Miq.) A. DC.

- leaves truncate

- margins of leaflets recurved or reflexed

- leaf petiole bearing no distinct pinnacanths or spines.

Stangeria T. Moore

- leaves plicate when young

- stipules have distinct vascular bundle within cross-section

- strobili terminal and attached to pedicel.

Zamia L.

- spinose or pectinate spines often present on both petiole and rachis

- trichomes often present.

(Zgurski et al., 2008)

APPENDIX 2: COMPLETE LIST OF CYCADALES IN LIVING COLLECTION

\section{Cycadaceae}

Cycas L. (100 accepted species; RBGE has 5 per cent)

C. circinalis $\mathrm{L}$.

C. pectinata Buch.-Ham.

C. revoluta Thunb.

C. rumphii Miq.

C. seemannii A. Braun

\section{Zamiaceae}

Bowenia Hook. Ex Hook. F. (two accepted species; RBGE has 50 per cent) B. serrulata (W. Bull) Chamb.

Ceratozamia Brongn. (20 extant taxa; RBGE has 15 per cent)

C. hildae G.P. Landry \& M.C. Wilson

C. kuesteriana Regel

C. robusta Miq.

Dioon Lindl. (13 accepted species; RBGE has 23 per cent)

D. edule Lindl.

D. mejiae Standl. \& L.O. Williams

D. spinulosum Dyer \& Eichler 
Encephalartos Lehm. (65 accepted species; RBGE has 16.9 per cent)

E. altensteinii Lehm.

E. bubalinus Melville

E. caffer (Thunb.) Lehm.

E. ferox Bertol. f.

E. friderici-guilielmi Lehm.

E. hildebrandtii A. Braun \& C.D. Bouché

E. lebomboensis I. Verd.

E. lehmannii Lehm.

E. natalensis R.A. Dyer \& I. Verd.

E. transvenosus Stapf \& Burtt Davy

E. villosus Lehm.

Lepidozamia Regel (two accepted species; RBGE has 100 per cent)

L. hopei Regel

L. peroffskyana Regel

Macrozamia Miq. (41 accepted species; RBGE has 4 per cent)

M. communis L.A.S. Johnson

M. moori F. Muell.

Stangeria T. Moore (one accepted species; RBGE has 100 per cent) S. eriopus (Kunze) Baill.

Zamia L. (57 accepted species; RBGE has 3 per cent)

Z. furfuracea L. f.

Z. integrifolia L. f. 